Binghamton University

The Open Repository @ Binghamton (The ORB)

9-28-2017

\title{
Size, Sustainability, and Urban Climate Planning in a Multilevel Governance Framework
}

George C. Homsy

Binghamton University--SUNY, ghomsy@binghamton.edu

Follow this and additional works at: https://orb.binghamton.edu/public_admin_fac

Part of the Public Administration Commons

\section{Recommended Citation}

Homsy, George C., "Size, Sustainability, and Urban Climate Planning in a Multilevel Governance Framework" (2017). Public Administration Faculty Scholarship. 44.

https://orb.binghamton.edu/public_admin_fac/44

This Book Chapter is brought to you for free and open access by the Public Administration at The Open Repository @ Binghamton (The ORB). It has been accepted for inclusion in Public Administration Faculty Scholarship by an authorized administrator of The Open Repository @ Binghamton (The ORB). For more information, please contact ORB@binghamton.edu. 


\title{
Size, Sustainability, and Urban Climate Planning in a Multilevel Governance Framework
}

\author{
George C. Homsy ${ }^{1}$
}

\begin{abstract}
In the United States, the absence of federal leadership on climate change and a strong tradition of localism has created a system in which many greenhouse gas reduction efforts fall to the discretion of municipalities. This often leads to uncoordinated action across jurisdictional boundaries. Despite the widespread notion that cities can lead on climate policy from the bottom up, I find, using a logistic regression analysis of data from 1,837 municipalities, that local governments are more likely to enact climate change policies in an environment where higher levels of government have acted rather than in a decentralized one. Smaller municipalities, in particular, have increased odds of action when engaged when their states act. Using existing regional, state-based initiatives, I present options for a coordination and capacity building framework.
\end{abstract}

\section{Introduction}

For much of its history, the United States has had trouble dealing with challenges of the commons or common pool resources, especially pollution and natural resource protection. The rapid industrialization of the United States following the Second World War came with horrendous water and air pollution; rivers caught fire and deadly smog suffocated regions with pollution flowing easily across jurisdictional borders. In 1948, thick air pollution originating in Donora, Pennsylvania's zinc industry killed 13 people and sickened thousands in that city and downwind in the neighboring city of Webster (Snyder 1994). Municipalities pumped wastewater into the rivers from which downstream neighbors pulled their drinking water (Holloway et al. 2014). Local leaders were unwilling to shoulder clean-up costs or impose them on industries that threatened to close factories and cut jobs (Andreen 2003). Starting in 1970, environmental protection over some issues in the United States was nationalized through the passage of more than a dozen new federal statues (Andrews 2006). The top-down imposition of command and control regulation cleaned much of the worst air and water pollution in the United States (Fiorino 2006).

Today, climate change represents "the ultimate commons problem" (Stavins 2010) (see Chapter 6: Sarynski). One approach to governing climate change involves the top-down imposition on local governments of rules by a central authority, such as a national government. This has made the U.S. a leader in environmental cleanup (Fiorino 2006). However, this approach does not work well in dealing with complex problems (Kettl 2002). Centralized,

\footnotetext{
${ }^{1}$ George C. Homsy

Assistant Professor

Department of Public Administration

Sustainable Communities Program

Binghamton University

Binghamton, New York 13902 USA

Email: ghomsy@binghamton.edu

Tel: 01-607-777-9184
} 
expert-driven solutions usually view all problems as if they are technical puzzles (Fiorino 2006) to be broken down like a machine and fixed piece-by-piece (Innes and Booher 2001). This approach is easy to administer, but does not reflect the complexity of the real world (Agranoff and McGuire 2003). Central mandates are traditionally command and control regulations, which provide little flexibility for adjusting to local conditions (Mazmanian and Kraft 1999). And, in the case of climate change, national level climate policies in the United States are weak to nonexistent. In 2015, President Barack Obama's Clean Power Plan, which imposed federal regulations on the coal-fired power plants, also issued $\mathrm{CO}_{2}$ emission goals for states. However, implementation has been delayed by lawsuits and the administration of President Donald Trump has begun to dismantle the plan.

The second approach to environmental protection focuses on local solutions without intervention from a central authority. A number of municipalities have undertaken greenhouse gas reduction efforts and the communities at this level of government have the potential to be important actors in the greenhouse gas reduction effort (Kousky and Schneider 2003; Gore and Robinson 2009). Developed as a theory of small-scale, common-pool resource management, this decentralized approach has been applied to climate issues (Ostrom 2010) and emphasizes local solutions to fit local problems (Nagendra and Ostrom 2012). It can ensure redundancy of potential solutions and increase accountability (Sovacool 2011). The mayor of one small city claimed that the most important climate change action would happen at the municipal level: "We will save the world one plan at a time, one initiative at a time, one strategy at a time... Make no mistake, we will save the world" (Homsy and Warner 2015). Despite such boasts and the extensive policy action in some big cities, adoption of municipality-based climate action plans and general sustainability policy actions remains low overall (Svara 2011; Homsy and Warner 2012). Further, a decentralized governance approach can result in negative externalities, spillovers, regional inequity, and capacity constraints (Howell-Moroney 2008; Pastor et al. 2009; Feiock 2013).

An emerging literature argues for multilevel governance as the framework for environmental sustainability including climate change (Bulkeley 2010; Homsy and Warner 2013; Balme and Qi 2014). While cities may initiate environmental protection, they must coordinate with each other, with regional and national governments, and with other non-state actors to be successful (Bulkeley and Betsill 2005). U.S. cities operate within complex governance systems and variations in local government outcomes may result from external factors, such as connections with non-governmental organizations and a central authority (Andersson and Ostrom 2008).

In this chapter, I use a survey of U.S. municipalities to test the hypothesis that jurisdictions will be more likely to adopt climate change policies in a multilevel governance environment that is encouraging of such action as opposed to a decentralized framework in which local governments must act on their own. In addition, I examine the role that a municipality's population size plays with the second hypothesis that smaller places will benefit more from a multilevel environment than bigger cities. The federated nature of the 50 American states provides a good laboratory for testing the importance of multilevel action versus a more polycentric one since each state has different regulations, policies, and incentives governing the policy options available to municipalities. Although no governance level (states, region, or federal) mandates local climate change mitigation by municipalities, some states have climate change plans and supportive policy and programmatic frameworks that may enhance emissions reduction efforts; others do not. In addition, groups of states are organized into regional 
initiatives specifically seeking reductions in greenhouse gas emissions; these organizations present another level of governance with which municipalities might interact.

I find municipalities take cues within a complex multilevel environment from a variety of internal and external drivers. Unlike much literature that argues decentralized municipal action on the environment is most effective, the data here show that municipalities in states supportive of climate change action are more likely to act, even without legal requirements to do so. The research also identifies internal factors that push climate mitigation. The combination of topdown and bottom-up factors indicate the advantage of multilevel governance in climate change mitigation.

The chapter also fills a hole in the literature regarding climate change actions across localities of different sizes. Sustainability and climate change research focuses on big cities, which are consistently described as leaders. However, most Americans live in small, often suburban municipalities. These smaller places have different relationships with state governments, different access to technical and fiscal capacity, and different political environments. I find that state influence and internal politics do act differently in communities of different population size and metropolitan status. Both sets of findings can reframe our understanding of local policymaking as it relates to regional and global commons issues. These understandings have important implications for research as well as policy. In the concluding section, I offer a policy approach that could bring multilevel governance to local action in the United States.

\section{$2 \quad$ American cities and climate action}

In the United States, the federal government has paid little attention to the climate policies of local governments. National climate change policy focuses on industrial sectors, especially the reduction of emissions from coal-fired power plants and the increase in motor vehicle fuel efficiency (Crane and Landis 2010). In 2009, the federal government announced the Partnership for Sustainable Communities, a multi-agency effort to craft a national vision for local sustainability, which included greenhouse gas emissions reduction. Although the Partnership supported scores of community and regional projects, particularly to improve coordination between land use and transportation planning, the program suffered funding losses and failed to develop the measures and tools necessary to establish concrete standards (Birch and Lynch 2012). The 2015 Clean Power Plan set goals for state emissions reductions, but two years later the plan was still held up in courts and in the spring of 2017, the administration of President Donald Trump began to withdraw from the plan's regulations and international commitments (Davenport and Rubin 2017).

Given the failures at the national and international levels, some have targeted municipalities as the appropriate scale for government action on climate change for four reasons. First, in an increasingly urbanized world, cities emit a significant portion of the greenhouse gases (Bulkeley 2010). Second, American municipalities can choose to construct energy efficient government buildings or retro-fit older ones; they can install more efficient street and traffic lights; and some experiment with alternative energy generation (Svara et al. 2011). Such strategies not only save power, but also model policies to the private sector. Third, local governments can impact (through incentives, regulations, or other policies) non-public activities within their borders by, for example, imposing green building requirements on private projects (Salkin 2009). Municipalities, through their land use regulations, can also require denser, more efficient developments or provide transportation alternatives to the private automobile (Jepson 
2004). Others, through their municipal electric utilities, have the ability to induce energy sustainability in the private sector (Homsy 2016). Fourth, cities will be first responders to potential climate-caused disasters (FEMA 2008).

Most research on climate change action in US cities examines large, urban centers or cities that are pioneers (e.g. Berry \& Portney, 2013; Bulkeley \& Betsill, 2003; Kousky \& Schneider, 2003; Tang, Brody, Quinn, Chang, \& Wei, 2010) However, in the United States, just over half of the population lives in smaller municipalities (fewer than 25,000 people). Only a quarter of Americans live in the fewer than 300 cities with more than 100,000 residents. Auto-centric American suburbs are the least carbon efficient (Glaeser and Kahn 2010) and rural commuting comprises a large and growing portion of total miles driven (Renkow and Hoover 2000).

The majority of municipalities do nothing about climate change. A 2010 national survey of American cities (Svara 2011) found that only 12 percent of responding municipalities have created a baseline of emissions or set reduction targets of some sort; 22 percent of respondents sought to reduce energy use in transportation fleets and outdoor light fixtures; only five percent offered energy audits to private businesses. Smaller communities lag larger ones in the adoption of general sustainability policies (Homsy and Warner 2012). The reasons why local governments, especially smaller ones, choose to act on climate change remains a significant gap in academic and practitioner understandings.

\section{Local governance of the global commons}

As more municipalities initiate efforts to mitigate climate change, there is a debate over whether local governments can will act on-their-own or not. Although no states mandate local government action on climate change, the states do have differing levels of commitment to the environmental challenge which can be conducive or not for policy action. In addition, numerous states have joined multi-state initiatives that focus on climate change mitigation. In this section, we discuss the theoretical foundations for two conflicting frameworks of local action on commons issues: decentralization and multilevel governance.

\subsection{Decentralized governance}

Decentralized governance is a public choice model in which the competition for residents and businesses drives the provision of public goods. It arose as metropolitan-level polycentrism in the 1960s, when Ostrom, Tiebout, and Warren (1961) demonstrated that some public services, such as policing and education, seemed to be best provided at the local level. They maintained that intermunicipal competition and local government's close connection to constituents result in cost-effective outcomes, local innovations, and a diversity of options. The actors in a decentralized system better understand local needs and thus better provide for local public goods than a higher authority (McGinnis 1999).

Elinor Ostrom (2009) hypothesized that this polycentric manner of public goods provision at the local level offers a model for the governance of the global commons. She contended that a variety of public and private actors (including municipalities, utilities, households, firms, nations, etc.) will be driven by competition and local advantages to create independent solutions to greenhouse gas reductions. Such a competitive approach to resource allocation envisions municipalities using strategies best suited to the local environment, citizenry, and other particulars of circumstance. Diffuse local action unburdens the dysfunctional international climate negotiation agenda by having priorities taken up by lower levels of government (Rayner 2010).

Benefits of local independent action include: more experimentation and innovation, local 
tailoring of action to fit circumstances, political testing of policies, and local experience in enforcement (see Chapter 16: Ninomiya and Burch). However, municipally-driven initiatives also have the potential to cause an economically ineffective patchwork of regulations, duplicative enforcement efforts, cross-boundary mismatches between pollution sources and effects, shuffling of high-carbon activities to weaker regulatory areas, and confusion over responsibility between levels of government (Lutsey and Sperling 2008). Local stakeholders acting on their own can grow frustrated with the lack of coordination and express the desire for a holistic approach to greenhouse gas mitigation (Greenwood 2012).

Some empirical analysis seems to indicate that municipalities can act on their own with regards to local climate action (Pitt 2010; Krause 2011a, b). For example, communities are more likely to act when climate change mitigation is linked to a policy already on the local government agenda (Betsill 2001). Such an approach reframes global problems are more local concerns (Metz and Below 2009) and ones on which local governments have the authority to act (see Chapter 12: Brown). These local co-benefits emerge in various forms, such as: reduction in energy costs (Kousky and Schneider 2003; Svara et al. 2011), increased public health (Bloomberg and Aggarwala 2008), or sustainable economic development and local job production (Jochem and Madlener 2003).

\subsection{Multilevel governance}

The multilevel governance framework emerged as a way to analyze and organize the new European Union's relationship to its member states (Bulkeley and Betsill 2003). This approach engages multiple tiers of government in a communicative process that requires the co-production of knowledge and policy up and down levels of authority (Corburn 2009; Homsy and Warner 2013). It requires a respect for local knowledge in the creation of place-specific policies. At the same time, it recognizes the role of a central authority, which has technical expertise as well as the ability to coordinate local governments and induce compliance through incentives or regulations (Homsy et al. 2016). Hooghe and Marks (2003) describe two types of governments within a multilevel framework: one is geographically bound while the other focuses on managing common pool resources across jurisdictions.

Unlike in Europe, the United States federal government rarely participates with local governments on climate issues, leading to uncoordinated efforts, differing goals, and inconsistent time horizons (Selin and VanDeveer 2009). In 2010, 35 states either had completed or were in the process of developing climate action plans (Center for Climate and Energy Solutions 2011). No states have mandated local government action. The closest is a 2008 California law that requires urban regions to meet greenhouse gas reduction goals by coordinating land use and transportation policy (Barbour and Deakin 2012). While an increasing number of states and regions continue to enact policies on climate change (Rabe 2009), most efforts focus on industry sectors, not local governments (Selin and VanDeveer 2009).

A multilevel framework is not completely foreign to American governance structures and has led to some environmental successes. The federal government in the United States has experimented with cooperative federalism, in which local and state governments participate in the implementation of federal standards (Fischman 2005). The U.S. Environmental Protection Agency engaged in a more co-productive relationship in an effort to clean the polluted Rouge River Watershed. By threatening to impose expensive top-down regulations, the federal government successfully built a coalition of local governments and private actors to cut water pollution, reduce the danger of toxic chemicals, and improve the habitat in the almost 1,200 square kilometer watershed (Homsy et al. 2016). 
While there have been some implicit (e.g. auto fuel efficiency standards) and explicit (e.g. 2015 Clean Power Plan) federal policies that have reduced greenhouse gas emissions, subnational governments remain the major drivers of action in the United States (Karapin 2016). The national government is absent due to the inability of most officials and citizens to see climate change impacts; the polarized state of the U.S. party system and the general ideology of limited government intervention; the lack of national authority over many issues; and the lack of strong international institutions (Hale 2010).

Some state governments in the United States have formed state-to-state horizontal networks on environmental issues with varying degrees of success. Water quality in the Great Lakes was dramatically improved through the creation in the 1950s of the Great Lakes Commission, as an advisor and advocate for clean water, and the Council of the Great Lakes Governors, which provided a regular forum for information flows among state leaders (Rabe 1999). In 2001, the Conference of New England Governors and Eastern Canadian Premiers created a climate action plan with aggressive greenhouse gas emissions targets while the Western Governors Association established clean energy goals aimed at new technology development (Rabe 2009). Such networks could lead to greater emissions reductions than single state efforts due to greater geography and population encompassed, potential for uniformity of regulation, ability to capitalize on shared resources and economies, and development of a shared regional vision (Engel 2005). However, these networks remain state-to-state affairs with plans encompassing only the state level of operations and rarely engaging or organizing local governments.

\section{$4 \quad$ Research Method}

This chapter seeks to empirically investigate the debate around the ability of local governments to act on climate change on their own versus the need for higher level government support. My first hypothesis is that municipalities are more likely to adopt climate change policies if they are within supportive states and regions. I also examine a second hypothesis that smaller municipalities will benefit more from such support than bigger cities. Testing these hypotheses requires finding situations that approximate multilevel governance of climate change in the United States.

This project takes advantage of a comprehensive survey of sustainability policymaking by U.S. municipalities. The 2010 Sustainability Survey, conducted by International City/County Management Association ${ }^{2}$, asked county and municipal leaders about their adoption of policies and programs in areas such as climate change, water quality protection and provision, building construction, and land use. Surveys were mailed to a sample of municipalities with populations of more than 2,500 people and fewer than 1,000,000 people. Within these parameters, managers of 7,257 local governments received surveys and 1,874 responded ( $25.8 \%$ response rate). Complete demographic, fiscal, and governance data was gathered for 1,837 municipalities, which represents the final number of local governments in the sample.

\subsection{Dependent Variable}

The dependent variable measures whether or not a community is a climate change actor. The variable is based on six climate change actions that a municipality might undertake. For each

\footnotetext{
${ }^{2}$ The survey was conducted in collaboration with researchers at Arizona State University's Center for Urban Innovation and ASU's Global Institute of Sustainability. A descriptive summary of the results can be found in Svara (2011).
} 
community, this dichotomous variable had a value of one (1) if officials indicated on the survey that their jurisdiction created any one or more of the following:

- A baseline of greenhouse gas emissions produced by the local government;

- A baseline of greenhouse gas emissions produced by the community;

- Greenhouse gas reduction targets for local government operations;

- Greenhouse gas reduction targets for businesses;

- Greenhouse gas reduction targets for multi-family residences; or

- Greenhouse gas reduction targets for single-family residences.

Establishing a baseline of emissions for either the local government or the community is a major undertaking for a municipality and indicates a commitment to climate change action. Adoption of the various targets can be symbolic, but also indicates an official intention by local leaders to address greenhouse gas emissions. Table 1 shows the percent of municipalities considered climate change action communities by population size. The adoption of policies is more prevalent among larger municipalities.

Table 1 - Distribution of climate change actor communities by population size

\begin{tabular}{l|c|c|c} 
Population size & $\begin{array}{c}\text { Percent climate } \\
\text { change actors }\end{array}$ & $\begin{array}{c}\text { Number of climate } \\
\text { change actors }\end{array}$ & $\begin{array}{c}\text { Total number of } \\
\text { communities in sample }\end{array}$ \\
\hline 2,500 to 9,999 & 8.1 & 69 & 848 \\
10,000 to 24,999 & 15.2 & 77 & 504 \\
25,000 to 99,999 & 34.7 & 135 & 389 \\
100,000 to 499,999 & 49.5 & 45 & 91 \\
500,000 to 999,999 & 60.0 & 3 & 5 \\
\hline Total & 17.9 & 329 & 1,837
\end{tabular}

\subsection{Independent variables}

The independent variables and the sources of the data are described in Table 2 and are grouped into following subject areas.

Multilevel variables. Two dichotomous variables examine the potential link between a multilevel governance framework and local government climate action. The first measures whether a municipality's state has a climate action plan, which was true for 327 municipalities in the sample. The second indicates whether the state is a member of a regional climate change initiative. In 2010, there were four regional initiatives (Western Climate Initiative, Regional Greenhouse Gas Initiative, Midwest Greenhouse Gas Reduction Accord, and the Transportation and Climate Initiative) that covered 14 states. The data includes 526 municipalities that were in states within one of the regional initiatives.

The following variables examine the internal drivers of climate action within communities.

Local politics variables. The first variable in this category indicates whether or not a community has a council-manager form of government, which research shows enact more innovative policies (Nelson and Svara 2012) including around issues of sustainability (Svara 2011). Second, I measure political attitudes, which can impact local sustainability policy in general and climate change in particular (Krause 2011a; Slavin 2011; Barbour and Deakin 2012). 
I employ an index of New Political Culture, which uses demographic information to predict local adoption of progressive policies. My index is based upon one developed by Saha (2009) and is built from the standardized values of the percentages in a jurisdiction of non-family households; unmarried households; people working in professional, scientific, technical, or educational jobs; residents between ages 18 and 44 years; women in workforce; and those who hold a bachelor's degree or higher.

Dominant economic players. Environmental protection is often seen as in conflict with economic development (Campbell 1996). However, three studies focusing on climate change show no correlation between the presence of manufacturing and climate policy action or general environmental sustainability (Krause 2011a; Sharp et al. 2011; Homsy and Warner 2015), though other studies indicate that local manufacturing decreases the chances that a community would act (Bulkeley and Betsill 2003; Gustavsson et al. 2009; Krause 2011b). Three variables test this conflict in the current study. The first is the 1999 to 2009 change in the number of jobs within the municipality's county, which represents general economic development. The other two variables are the percentage of people employed in agriculture/extractive operations and in manufacturing.

Local capacity variables. Local capacity examines the ability of a municipality to carry out policies, including climate change planning. Local government revenue per capita measures the ability of a community to raise funds through taxes and fees and thus fund policymaking and programming. Educational attainment (percentage of the population with a bachelor's degree or more) is a measure of the potential for community members to provide volunteer expertise. Finally, per capita income has been shown to correlate with general sustainability policies (Lubell et al. 2009) and climate change action in particular (Zahran et al. 2008; Sharp et al. 2011). 
Table 2 - Summary statistics for variables

\begin{tabular}{|c|c|c|c|c|}
\hline \multirow{2}{*}{ Variables } & \multicolumn{4}{|c|}{ Municipalities $(\mathrm{n}=1,837)$} \\
\hline & $\begin{array}{l}\text { Mean } \\
\text { (or percent } \\
\text { 'yes' for } 1 / 0 \\
\text { variables) }\end{array}$ & St. Dev. & Minimum & Maximum \\
\hline Dependent variable & & & & \\
\hline Climate change actor ${ }^{\mathrm{a}}(1=\mathrm{yes})$ & 17.8 & NA & 0 & 1 \\
\hline \multicolumn{5}{|l|}{$\underline{\text { Independent variables }}$} \\
\hline \multicolumn{5}{|l|}{ External factors } \\
\hline State climate plan $^{\mathrm{b}}(1=\mathrm{yes})$ & 64.1 & NA & 0 & 1 \\
\hline $\begin{array}{l}\text { State participation in regional climate } \\
\text { initiative }(1=\mathrm{yes})^{\mathrm{b}}\end{array}$ & 28.6 & NA & 0 & 1 \\
\hline \multicolumn{5}{|l|}{ Internal factors } \\
\hline \multicolumn{5}{|l|}{$\underline{\text { Local politics }}$} \\
\hline City manager government (1=yes) & 62.0 & NA & 0 & 1 \\
\hline Progressive political culture index & 1.98 & 11.7 & -5.97 & 10.5 \\
\hline \multicolumn{5}{|l|}{$\underline{\text { Dominant economic players }}$} \\
\hline Employment change $99-09^{\mathrm{g}}$ (percent) & 4.1 & 19.6 & -57.5 & 178.9 \\
\hline Agricultural employment ${ }^{\mathrm{d}}$ (percent) & 2.7 & 3.8 & 0 & 27.4 \\
\hline Manufact. employment ${ }^{\mathrm{d}}$ (percent) & 12.5 & 6.1 & 0.7 & 67.1 \\
\hline \multicolumn{5}{|l|}{ Local capacity } \\
\hline Local govt. rev. per capita ${ }^{\mathrm{e}}(\$ 1000 \mathrm{~s})$ & 984 & 949 & 0 & 18,280 \\
\hline Educ. att. (bachelor plus) ${ }^{\mathrm{d}}$ (percent) & 28.6 & 16.1 & 2.4 & 86.8 \\
\hline Per capita income ${ }^{\mathrm{d}}(\$)$ & 27,883 & 12,770 & 6,399 & 124,327 \\
\hline \multicolumn{5}{|l|}{$\underline{\text { Sociodemographic controls }}$} \\
\hline Central cities (1=yes) & 9.3 & NA & 0 & 1 \\
\hline Suburban municipalities ( $1=y e s$ ) & 59.2 & NA & 0 & 1 \\
\hline Rural communities (1=yes) & 31.5 & NA & 0 & 1 \\
\hline Population $^{\mathrm{f}}$ & 27,876 & 54,461 & 1,997 & 741,206 \\
\hline Pop. change $2000-2010^{\mathrm{f}}$ (percent) & 13.8 & 31.8 & -36.6 & 510.8 \\
\hline
\end{tabular}

${ }^{\text {a }}$ derived from ICMA Sustainability Survey, 2010

${ }^{\mathrm{b}}$ Center for Climate and Energy Solutions, 2011

${ }^{\mathrm{c}}$ Lublin \& Voss, 2001 d American Community Survey, 2005-2009

${ }^{\mathrm{e}}$ Census of Local Governments, 2002

${ }^{\mathrm{f}}$ U.S. Census 2010

${ }^{g}$ County Business Patterns, 1999-2009 


\section{$5 \quad$ Analysis of results}

The research hypotheses were tested using a series of six logistic models. Since the local governments are clustered within states, I used a hierarchical approach to control for the influence of states beyond the state climate variable tested. The first three models include just the presence of a state climate action plan across communities differentiated by population size: municipalities with populations of more than 25,000 people $(n=485)$; smaller communities between 2,500 and 25,000 in size $(n=1,352)$; and the entire sample $(n=1,837)$. Models four, five, and six include the state's participation in a regional initiative as an additional factor, again across the different-sized local governments. If municipalities operate in a purely polycentric manner, then the influence of the state and regional initiative will be insignificant. If top-down factors push climate change action, then internal drivers will be small or insignificant. The results of the logistic regression models are presented as odds ratios in Table 3 .

The results support the main hypothesis that multiple factors - internal and external positively correlate with the increased odds that a municipality undertakes climate change planning. The first external factor, the presence of a state climate plan, increases the odds of local action from 1.867 times to more than 2.431 times in five of the six models - even though no state plan directly requires action by municipalities. The exception is model five, focused on bigger citiesLOL, in which the presence of a state plan is insignificant, but the other external variable, regional initiative, correlated to increased odds of local climate change planning by 3.546 times. $^{3}$ At the same time, internal drivers are also significant and sizable.

The significance of multilevel drivers contradicts the results of some previous research, which finds that municipalities act independently on this issue and that states play no role in local climate action (Pitt 2010; Krause 2011a, b). Two factors might account for this divergence in findings. First, the dataset in the current study is larger and broader. In her two studies, Krause only examines places with populations greater than 25,000 and 50,000 respectively. The second factor is the difference in the construction of the dependent variables. In one study, Krause (2011a) uses the U.S. Mayors Climate Protection Agreement as a dependent variable, which requires neither the resource investment of a greenhouse gas inventory process nor the political capital needed to adopt emissions reductions targets.

The second Krause study (2011b) and Pitt (2010) employ as the dependent variable an additive index of policies which could reduce greenhouse gas emissions. However, many of the included policies (e.g. tree ordinances, recycling, bike lanes, public transit incentives, and encouragement of mixed-use/pedestrian-oriented development) need not have been undertaken with the intention of reducing emissions. Do a community's efforts to encourage public transit, for example, derive from a desire to fight climate change or to reduce congestion or provide transportation to low-income residents? To a practitioner, these differences are not important because the multiple facets broaden the pool of policy supporters. However, researchers seeking to study climate change need to make such distinctions; otherwise we are simply testing smart growth or general sustainability (see Chapter 4: Boswell and Mason). The dependent variable in the current study is targeted to a community's actions (emissions baselines) and intentions (adopted goals and targets) and represent specific climate change policy commitments. It offers a clear measure of policy intention and such precision is important if we are to understand what drives climate change policy at the local level.

\footnotetext{
${ }^{3}$ The models were also run without the presence of the multilevel variables and the results for the internal factors changed little in the six models.
} 
Table 3 - Results of multilevel logistic regression

\begin{tabular}{|c|c|c|c|c|c|c|}
\hline \multirow{4}{*}{ Model } & \multicolumn{3}{|c|}{ State climate plan } & \multicolumn{3}{|c|}{ State climate plan \& regional initiative } \\
\hline & 1 & 2 & 3 & 4 & 5 & 6 \\
\hline & All & Large & Small & All & Large & Small \\
\hline & $(\mathrm{n}=1,837)$ & $(n=485)$ & $(\mathrm{n}=1,352)$ & $(\mathrm{n}=1,837)$ & $(\mathrm{n}=485)$ & $(\mathrm{n}=1,352)$ \\
\hline Multilevel factors & \multicolumn{6}{|c|}{ Results presented as odds ratios } \\
\hline State climate plan & $* * 2.335$ & $* 2.132$ & $* * 2.431$ & $* 1.867$ & 1.508 & $* 2.173$ \\
\hline Regional initiative & & & & $* 1.738$ & $* * 3.546$ & 1.271 \\
\hline \multicolumn{7}{|l|}{ Internal factors } \\
\hline \multicolumn{7}{|l|}{ Local politics } \\
\hline City manager government & 1.120 & 1.332 & 1.074 & 1.151 & 1.534 & 1.081 \\
\hline Progress. political culture index & $* * 1.252$ & $* * 1.388$ & $* * 1.208$ & $* * 1.249$ & $* * 1.390$ & $* * 1.205$ \\
\hline \multicolumn{7}{|l|}{ Economic dependence } \\
\hline Employment change 99-09 & 0.998 & 0.997 & 0.998 & 0.998 & 0.995 & 0.998 \\
\hline Agricultural employment & 1.006 & 1.062 & 0.994 & 1.013 & 1.071 & 0.996 \\
\hline Manufacturing employ. & $* 0.965$ & 0.987 & $* 0.944$ & 0.969 & 0.996 & $* 0.947$ \\
\hline \multicolumn{7}{|l|}{ Local capacity } \\
\hline Local govt. rev. per capita (1000s) & $* * 1.257$ & $* * 1.638$ & $* 1.202$ & $* * 1.241$ & $* 1.402$ & $* 1.508$ \\
\hline Educ. att. (bachelor plus) & $* 1.020$ & 0.989 & $* 1.031$ & $* * 1.020$ & 0.986 & $* * 1.031$ \\
\hline Per capita income (1000s) & 0.990 & 1.042 & 0.977 & 0.989 & 1.045 & 0.976 \\
\hline \multicolumn{7}{|l|}{ Control variables } \\
\hline Central cities & & Reference & & & Reference & \\
\hline Suburban municipalities & 0.641 & 0.559 & 0.865 & 0.631 & $* 0.511$ & 1.822 \\
\hline Rural communities & $* 0.552$ & 0.606 & 0.465 & 0.561 & 0.648 & 1.456 \\
\hline 2010 Population (logged) & $* * 1.629$ & $* 1.564$ & $* 1.503$ & $* * 1.662$ & $* * 1.691$ & $* 1.547$ \\
\hline Pop. change 2000-2010 & 0.997 & 0.999 & 0.993 & 0.998 & 1.001 & 0.994 \\
\hline
\end{tabular}

$*$ indicates significance at the 0.05 level $* *$ indicates significance at the 0.01 level 
The secondary hypothesis, that smaller municipalities would benefit more in a multilevel environment than larger cities, is also largely supported. The impact of a state climate plan is greater among small municipalities (models three and six) than larger ones (models two and five, where it is insignificant). Participation in a regional climate change initiative produces no benefit to smaller places while it increases the odds of climate change planning in larger places. In bigger cities, fiscal and technical capacity pose less of a challenge; this frees them up to more fully engage in the discourse and positive environment created by a state that has taken the extra step of joining a regional initiative. Smaller places, however, may remain tied to their states on which they rely for fiscal and technical capacity as well as political cover. This is an important difference between larger and smaller municipalities. Population change and density are not significant in any model.

One of the internal variables, percentage of manufacturing employment, also indicates an important difference between larger places, where it is not significant, and smaller places, where it has a negative correlation to the odds of climate change planning. In smaller communities, the power of such dominant economic players could work against greenhouse gas reduction by local governments; in these small places, factory management and large numbers of employees would hold the most sway. Manufacturing interests have less power in bigger cities with more diverse voter and tax bases. The other two economic variables, employment change between 1999 and 2009 and level of agricultural employment, are not significant.

Two variables test form of government and political progressiveness - important internal factors. The form of government variable (presence of a council manager) is not significant, which is opposite of what was expected given the innovative nature of managers. Despite the rhetoric, climate change planning is still a pioneering action (Kern and Bulkeley, 2009; Portney, 2013; Tang, et al. 2010), perhaps still so new that the typical advantages of city manager forms of government do not apply. Political progressiveness, another internal driver and tested in the form of the Progressive Political Culture Index, was significant across all six models.

Educational attainment, a measure of local capacity to act, was most important in smaller places. Larger places may have staff and resources to drive climate mitigation policies, but in smaller places, capacity may have to come from the populace. Local government revenue per capita, which describes a local government's ability to act on its own, was significant across all six models.

\section{Creating a multilevel governance framework for climate action}

My analysis of a broad municipal dataset indicates that a multilevel governance framework facilitates more climate change planning by local governments than a decentralized approach. Without some leadership by state governments, larger cities will pioneer local climate change action, but the vast majority of cities will do nothing independently. Unlike in Europe where some national governments and the European Union took up the cause of climate change (in word if not in deed), the U.S. lacks an overarching climate framework for municipalities. The question for practitioners and policy makers is identifying the programs that will provide supportive environments at the state or regional level. Municipalities across metropolitan regions have coordinated to achieve affordable housing, economic development, open space conservation, and watershed protection goals (Wheeler, 2002). States are the more traditional mechanism with the existing legal authority to structure municipality actions (Frug and Barron, 2008), though this goes largely unused with regards to climate change. 
Here I want to introduce a potential approach to fostering the kind of governance environment that could induce local government action. This new kind of regionalism builds on a supra-state structure already existing in the regional climate change initiatives around the U.S., such as the Regional Greenhouse Gas Initiative or the Western Climate Initiative. These state-tostate projects have little direct interaction with municipalities, but, as our findings demonstrate, they do create a supportive environment for climate mitigation in larger cities. As organizations of states, they have the authority to require or incentivize greenhouse gas reductions in all municipalities in the multistate region.

The strength of these multi-state regions over single state or metropolitan regional governance is their broader geographic scope, which can more effectively eliminate free-rider problems and reduce leakage that pushes polluting industry to states or municipalities with less stringent regulations. States and municipalities may simply be too small geographically and economically to be effective. In the proposed multilevel structure, central knowledge could be gathered and targeted to specific regional initiatives. Innovative policies developed by local governments could be more relevant to other members of the region. For example, municipalities in the northeast could band together around reducing their natural gas emissions, while those in coal-producing states can develop shared outcomes for their challenges.

The recognized ineffectiveness of voluntary networks (Kern and Bulkeley, 2009) might stem from their national or international scope; they are a coalition of communities with interests that are simply too different. Multi-state regions might be more effective at incentivizing or requiring action because the states (and their municipalities) within these new geographically based regional networks will more likely share economic goals and political constituencies. For example, the cap and trade program run by Regional Greenhouse Gas Initiative (RGGI) in the northeastern United States, which also provides technical capacity to states, realized a net positive economic impact of $\$ 1.6$ billion (Hibbard et al., 2011). Such successes make membership and action enticing, especially when states share geography, weather, negative impacts of a changing climate, and economic situation. In the case of RGGI, for example, none of the current nine-member state governments produce coal within their borders. If RGGI tried to add coal-producing Pennsylvania to the mix, it is likely the network would become unstable and policy innovations would prove to be less common to all members. In some ways, the boundaries approximate a European nation with a common heritage, similar climate, and comparable economic situation.

\section{Conclusion}

Much has been written describing the contents and effectiveness of climate change planning by local governments. Less well investigated is the motivation for local action on such a global commons problem. My analysis of 1,837 municipalities indicates that both internal and external factors drive climate change action in those places that do act. Since most communities simply have not adopted climate policies on their own as expected by proponents of decentralized theories of urban policymaking, policymakers need to create a supportive multilevel environment that recognizes the importance of top-down goal setting and sanctioning power with bottom up knowledge and buy-in (Homsy and Warner 2013).

Despite the hype, municipal level climate action planning remains disappointingly low. The new US administration of President Trump has called climate change a hoax and, therefore, will likely provide no new - and probably dismantle existing - federal efforts (Davenport 2017). Planners and other policymakers must realize that the hope for a locally-driven, bottom-up 
approach to climate change will remain limited to pioneering municipalities, even under the best of circumstances. In the absence of federal oversight, state and municipal leaders might build on existing regional networks that group "like" states together and create a multilevel structure within which, this analysis indicates, local action is more likely to thrive.

\section{References}

Agranoff, R., \& McGuire, M. (2003). Collaborative public management: new strategies for local governments. Washington, DC: Georgetown University Press.

Andersson, K. P., \& Ostrom, E. (2008). Analyzing decentralized resource regimes from a polycentric perspective. Policy Sciences, 41(1), 71-93. doi:10.1007/s11077-007-9055-6.

Andreen, W. L. (2003). The Evolution of Water Pollution Control in the United States - State, Local, and Federal Efforts, 1789-1972: Part 1. Stanford Environmental Law Journal, 22, 145-200.

Andrews, R. N. L. (2006). Managing the Environment, Managing Ourselves: A History of American Environmental Policy. New Haven, CT: Yale University Press.

Balme, R., \& Qi, Y. (2014, June 5). Multi-Level Governance and the Environment: Intergovernmental Relations and Innovation in Environmental Policy. Environmental Policy \& Governance, pp. 147-154.

Barbour, E., \& Deakin, E. A. (2012). Smart Growth Planning for Climate Protection. Journal of the American Planning Association, 78(1), 70-86. doi:10.1080/01944363.2011.645272.

Berry, J. M., \& Portney, K. E. (2013). Sustainability and Interest Group Participation in City Politics. Sustainability, 5(5), 2077-2097. doi:10.3390/su5052077.

Betsill, M. (2001). Mitigating climate change in US cities: Opportunities and obstacles. Local Environment, 6(4), 393-406.

Birch, E. L., \& Lynch, A. (2012). Measuring U.S. Sustainable Urban Development. In L. Starke (Ed.), State of the World 2012 (pp. 77-86). Island Press/Center for Resource Economics.

http://www.springerlink.com.proxy.library.cornell.edu/content/r439228522h85m79/abstract/. Accessed 1 July 2012

Bloomberg, M. R., \& Aggarwala, R. T. (2008). Think Locally, Act Globally: How Curbing Global Warming Emissions Can Improve Local Public Health. American Journal of Preventive Medicine, 35(5), 414-423. doi:16/j.amepre.2008.08.029.

Bulkeley, H. (2010). Cities and the Governing of Climate Change. Annual Review of Environment and Resources, 35(1), 229-253. doi:10.1146/annurev-environ-072809-101747.

Bulkeley, H., \& Betsill, M. (2003). Cities and climate change: urban sustainability and global environmental governance. London: Routledge.

Bulkeley, H., \& Betsill, M. (2005). Rethinking Sustainable Cities: Multilevel Governance and the "Urban" Politics of Climate Change. Environmental Politics, 14(1), 42-63. doi:10.1080/0964401042000310178.

Campbell, S. (1996). Green Cities, Growing Cities, Just Cities?: Urban Planning and the Contradictions of Sustainable Development. Journal of the American Planning Association, 62(3), 296-312.

doi:10.1080/01944369608975696.

Center for Climate and Energy Solutions. (2011). U.S. Cities and States. https://www.c2es.org/us-states-regions. Accessed 25 May 2012.

Corburn, J. (2009). Cities, Climate Change and Urban Heat Island Mitigation: Localising Global Environmental Science. Urban Studies, 46(2), 413-427. doi:10.1177/0042098008099361.

Crane, R., \& Landis, J. (2010). Introduction to the Special Issue. Journal of the American Planning Association, 76(4), 389-401. doi:10.1080/01944363.2010.512036. 
Municipal climate action in US - page 14 of 17

Davenport, C. (2017, January 21). Climate Change References Are Purged From Website. The New York Times, p. A20. New York.

Davenport, C., \& Rubin, A. J. (2017, March 28). Trump Signs Executive Order Unwinding Obama Climate Policies. The New York Times. https://www.nytimes.com/2017/03/28/climate/trump-executive-order-climate-change.html. Accessed 29 March 2017.

Engel, K. H. (2005). Mitigating Global Climate Change in the United States: A Regional Approach. NYU Environmental Law Journal, 14, 55-86.

Feiock, R. C. (2013). The Institutional Collective Action Framework. Policy Studies Journal, 41(3), 397-425. doi:10.1111/psj.12023.

FEMA. (2008). National Response Framework. Washington, DC: Department of Homeland Security.

Fiorino, D. J. (2006). The New Environmental Regulation. Cambridge, MA: The MIT Press.

Fischman, R. L. (2005). Cooperative Federalism and Natural Resources Law. New York University Environmental Law Journal, 14, 179.

Glaeser, E. L., \& Kahn, M. E. (2010). The greenness of cities: carbon dioxide emissions and urban development. Journal of Urban Economics, 67(3), 404-418.

Gore, C., \& Robinson, P. (2009). Local Government Response to Climate Change: Our Last, Best Hope? In H. Selin \& S. D. VanDeveer (Eds.), Changing Climates in North American Politics: Institutions, Policymaking, and Multilevel Governance (pp. 137-158). Cambridge, MA: The MIT Press.

Greenwood, D. (2012). The challenge of policy coordination for sustainable sociotechnical transitions: the case of the zero-carbon homes agenda in England. Environment and Planning C: Government and Policy, 30(1), 162 - 179. doi:10.1068/c1146.

Gustavsson, E., Elander, I., \& Lundmark, M. (2009). Multilevel governance, networking cities, and the geography of climate-change mitigation: two Swedish examples. Environment and Planning C: Government and Policy, 27(1), 59 - 74. doi:10.1068/c07109j.

Hale, S. (2010). The new politics of climate change: why we are failing and how we will succeed. Environmental Politics, 19(2), 255-275. doi:10.1080/09644010903576900.

Holloway, C. F., Strickland, C. H., Gerrard, M. B., \& Firger, D. M. (2014). Solving the CSO Conundrum: Green Infrastructure and the Unfulfilled Promise of Federal-Municipal Cooperation. Harvard Environmental Law Review, $38,335-369$.

Homsy, G. C. (2016). Powering sustainability: Municipal utilities and local government policymaking. Environment and Planning C: Government and Policy, 34(6), 1076-1094. https://doi.org/10.1177/0263774X15596530.

Homsy, G. C., Liu, Z., \& Warner, M. E. (2016, December 28). Finding the Center in Multilevel Governance: Comparing U.S. and China Environmental Cleanup Efforts. Unpublished, Binghamton, NY.

Homsy, G. C., \& Warner, M. E. (2012). Off the Beaten Path: Sustainability Activities in Small Towns and Rural Municipalities. In Municipal Year Book 2012 (pp. 53-61). Washington, DC: ICMA Press.

Homsy, G. C., \& Warner, M. E. (2013). Climate Change and the Co-Production of Knowledge and Policy in Rural USA Communities. Sociologia Ruralis, 53(3), 291-310. doi:10.1111/soru.12013.

Homsy, G. C., \& Warner, M. E. (2015). Cities and Sustainability Polycentric Action and Multilevel Governance. Urban Affairs Review, 51(1), 46-73. doi:10.1177/1078087414530545.

Hooghe, L., \& Marks, G. (2003). Unraveling the Central State, but How? Types of Multi-Level Governance. The American Political Science Review, 97(2), 233-243.

Howell-Moroney, M. (2008). The Tiebout Hypothesis 50 Years Later: Lessons and Lingering Challenges for Metropolitan Governance in the 21st Century. Public Administration Review, 68(1), 97-109. doi:10.1111/j.15406210.2007.00840.x.

Innes, J. E., \& Booher, D. E. (2001). Indicators for sustainable communities: a strategy building on complexity 
theory and distributed intelligence. Planning theory \& practice, 1(2), 173-186.

Jepson, E. J. (2004). The Adoption of Sustainable Development Policies and Techniques in U.S. Cities: How Wide, How Deep, and What Role for Planners? Journal of Planning Education and Research, 23(3), 229-241. doi:10.1177/0739456X03258638.

Jochem, E., \& Madlener, R. (2003). The forgotten benefits of climate change mitigation: Innovation, technological leapfrogging, employment, and sustainable development. In Workshop on the Benefits of Climate Policy: Improving Information for Policy Makers. Paris: Organization for Economic Co-operation and Development. http://www.oecd.org/env/cc/19524534.pdf.

Karapin, R. (2016). Political Opportunities for Climate Policy: California, New York, and the Federal Government. New York: Cambridge University Press.

Kettl, D. F. (2002). The transformation of governance: public administration for twenty-first century America. Baltimore, MD: John Hopkins University Press.

Kousky, C., \& Schneider, S. H. (2003). Global climate policy: will cities lead the way? Climate Policy, 3(4), 359372.

Krause, R. M. (2011a). Policy innovation, intergovernmental relations, and the adoption of climate protection initiatives by U.S. cities. Journal of Urban Affairs, 33(1), 45-60. doi:10.1111/j.1467-9906.2010.00510.x.

Krause, R. M. (2011b). An assessment of the greenhouse gas reducing activities being implemented in US cities. Local Environment, 16(2), 193-211. doi:10.1080/13549839.2011.562491.

Lubell, M., Feiock, R. C., \& Handy, S. (2009). City Adoption of Environmentally Sustainable Policies in California's Central Valley. Journal of the American Planning Association, 75(3), 293-308. doi:10.1080/01944360902952295.

Lutsey, N., \& Sperling, D. (2008). America's bottom-up climate change mitigation policy. Energy Policy, 36(2), 673-685. doi:10.1016/j.enpol.2007.10.018.

Mazmanian, D. A., \& Kraft, M. E. (1999). The Three Epochs of the Environmental Movement. In D. A. Mazmanian \& M. E. Kraft (Eds.), Toward Sustainable Communities: Transition and Transformations in Environmental Policy (pp. 3-41). Cambridge, Massachusetts: The MIT Press.

McGinnis, M. (1999). Introduction. In McGinnis, Michael (Ed.), Polycentric Governance and Development (pp. 128). Ann Arbor, MI: The University of Michigan Press.

Metz, D., \& Below, C. (2009). Local land use and climate change policy: summary report from focus groups and interviews with local officials in the Intermountain West (Working Paper No. WP09DM2). Cambridge, MA: Lincoln Institute of Land Policy.

Nagendra, H., \& Ostrom, E. (2012). Polycentric governance of multifunctional forested landscapes. International Journal of the Commons, 6(2), 104-133.

Nelson, K. L., \& Svara, J. H. (2012). Form of Government Still Matters Fostering Innovation in U.S. Municipal Governments. The American Review of Public Administration, 42(3), 257-281. doi:10.1177/0275074011399898.

Ostrom, E. (2009). A polycentric approach for coping with climate change (Policy Research Working Paper No. 5095). Washington, DC: World Bank.

Ostrom, E. (2010). Polycentric systems for coping with collective action and global environmental change. Global Environmental Change, 20(4), 550-557. doi:16/j.gloenvcha.2010.07.004.

Ostrom, V., Tiebout, C. M., \& Warren, R. (1961). The Organization of Government in Metropolitan Areas: A Theoretical Inquiry. The American Political Science Review, 55(4), 831-842. doi:10.2307/1952530.

Pastor, M., Lester, T. W., \& Scoggins, J. (2009). Why Regions? Why Now? Who Cares? Journal of Urban Affairs, 31(3), 269-296.

Pitt, D. (2010). The impact of internal and external characteristics on the adoption of climate mitigation policies by US municipalities. Environment and Planning C: Government and Policy, 28(5), 851-871. 
Rabe, B. G. (1999). Sustainability in a Regional Context: The Case of the Great Lakes Basin. In D. A. Mazmanian \& M. E. Kraft (Eds.), Toward Sustainable Communities: Transition and Transformations in Environmental Policy (pp. 247-281). Cambridge, Massachusetts: The MIT Press.

Rabe, H. (2009). Second-Generation Climate Policies in the States: Poliferation, Diffusion, and Regionalization. In H. Selin \& S. D. VanDeveer (Eds.), Changing Climates in North American Politics: Institutions, Policymaking, and Multilevel Governance (pp. 67-85). Cambridge, MA: The MIT Press.

Rayner, S. (2010). How to Eat an Elephant: A Bottom-up Approach to Climate Policy. Climate Policy, 10(6), 615621.

Renkow, M., \& Hoover, D. (2000). Commuting, Migration, and Rural-Urban Population Dynamics. Journal of Regional Science, 40(2), 261-287. doi:10.1111/0022-4146.00174.

Saha, D. (2009). Factors Influencing Local Government Sustainability Efforts. State and Local Government Review, 41(1), 39-48. doi:10.1177/0160323X0904100105.

Salkin, P. E. (2009). Sustainability and Land Use Planning: Greening State and Local Land Use Plans and Regulations to Address Climate Change Challenges and Preserve Resources for Future Generations. William \& Mary Environmental Law and Policy Review, 34, 1-50.

Selin, H., \& VanDeveer, S. D. (2009). North American Climate Governance: Policymaking and Institutions in the Multilevel Greenhouse. In H. Selin \& S. D. VanDeveer (Eds.), Changing Climates in North American Politics: Institutions, Policymaking, and Multilevel Governance (pp. 305-325). Cambridge, MA: The MIT Press.

Sharp, E. B., Daley, D. M., \& Lynch, M. S. (2011). Understanding Local Adoption and Implementation of Climate Change Mitigation Policy. Urban Affairs Review, 47(3), 433-457. doi:10.1177/1078087410392348

Slavin, M. I. (2011). Where Sustainability Stands Now: Contemporary Trends and Future Prospects. In M. I. Slavin (Ed.), Sustainability in America's Cities (pp. 231-246). Washington, DC: Island Press/Center for Resource Economics. Accessed 22 March 2012

Snyder, L. P. (1994). "The Death-Dealing Smog over Donora, Pennsylvania": Industrial Air Pollution, Public Health Policy, and the Politics of Expertise, 1948-1949. Environmental History Review, 18(1), 117-139.

doi: $10.2307 / 3984747$

Sovacool, B. K. (2011). An international comparison of four polycentric approaches to climate and energy governance. Energy Policy, 39(6), 3832-3844. doi:10.1016/j.enpol.2011.04.014.

Stavins, R. N. (2010). The Problem of the Commons: Still Unsettled After 100 Years. National Bureau of Economic Research Working Paper Series, No. 16403. http://www.nber.org/papers/w16403. Accessed 13 September 2011

Svara, J. H. (2011). The Early Stage of Local Government Action to Promote Sustainability. In The Municipal Year Book 2011 (pp. 43-60). Washington, DC: ICMA Press.

Svara, J. H., Read, A., \& Moulder, E. (2011). Breaking New Ground: Promoting Environmental and Energy Programs in Local Government. Washington, DC: IBM Center for the Business of Government.

Tang, Z., Brody, S. D., Quinn, C., Chang, L., \& Wei, T. (2010). Moving from agenda to action: evaluating local climate change action plans. Journal of Environmental Planning and Management, 53(1), 41-62.

doi:10.1080/09640560903399772.

Zahran, S., Grover, H., Brody, S. D., \& Vedlitz, A. (2008). Risk, Stress, and Capacity Explaining Metropolitan Commitment to Climate Protection. Urban Affairs Review, 43(4), 447-474. doi:10.1177/1078087407304688. 